THEMATIC ARTICLES

ARTYKUŁY TEMATYCZNE

EETP Vol. 15, 2020, №. 3(57)

ISSN $1896-2327$ / e-ISSN 2353-7787

DOI: $10.35765 /$ eetp.2020.1557.01

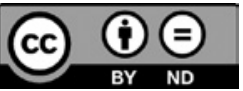

Submitted: 15.05 .2020

Accepted: 22.07 .2020

Suggested citation: Turczyk M., Jaskulska S. (2020). Distance education and children's rights: New dimensions of school exclusion during the COVID-19 outbreak, "Elementary Education in Theory and Practice," vol. 15, no. 3(57), pp. 9-20.

DOI: 10.35765/eetp.2020.1557.01

\author{
Małgorzata Turczyk \\ ORCID: 0000-0003-4095-9294 \\ Jagiellonian University in Krakow \\ Sylwia Jaskulska \\ ORCID: 0000-0002-3454-7894 \\ Adam Mickiewicz University in Poznań
}

\title{
Distance Education and Children's Rights: New Dimensions of School Exclusion During the COVID-19 Outbreak
}

\author{
Kszłałcenie na odległość a prawa dziecka - nowe \\ wymiary szkolnej ekskluzji w czasach epidemii \\ COVID-19
}

\section{KEYWORDS}

distance learning, children's rights, exclusion, school exclusion, COVID-19

\section{ABSTRACT}

The aim of this article is to analyze distance learning, which was introduced in Poland during the COVID-19 outbreak, in the context of children's rights. The main issues discussed herein are connected with incidents of excluding students and failing to respect their rights. The right to education of those children who do not have the conditions to fulfill their obligation of compulsory online schooling is not our only concern. This article also touches on the issue of school's insufficient guardianship and protective function and, in consequence, the aggravation of inequalities between people with lower and higher family income. The analysis is based on the authors' appeal that was disseminated in April 2020 by Komitet Ochrony Praw Dzieci [Committee for the Protection of Children's Rights] and the Ja Teacher'ka [I Teacher] foundation. 
The study was based on a perusal of the literature on the subject and a legal and normative scrutiny of the binding legal acts on distance learning. The first section presents the school as an institution of normative inclusion in the historical and contemporary perspectives. In the second part, we shed light on areas of exclusion in the context of the changes introduced in connection with the pandemic.

\section{SŁOWA KLUCZE ABSTRAKT}

kształcenie na Celem tekstu jest ukazanie kształcenia na odległość, które zostało odległość, prawa wprowadzone w Polsce w czasie epidemii COVID-19, w kontekście dziecka, ekskluzja, prawa dziecka. Główne wątki są skoncentrowane wokół przejawów szkolna ekskluzja, wykluczania uczniów i uczennic oraz nierealizowania ich praw. Nie COVID-19 chodzi tylko o prawo do nauki tych dzieci, które nie mają warunków do realizowania obowiązku szkolnego online, ale też o niedostateczne pełnienie przez szkołę funkcji opiekuńczej i wychowawczej oraz pogłębianie w konsekwencji nierówności między osobami o niższym i wyższym kapitale rodzinnym. Podstawą tekstu jest manifest autorek upowszechniony w kwietniu 2020 roku na stronach Komitetu Ochrony Praw Dziecka i Fundacji Ja Nauczyciel'ka. Badania oparto na metodzie analizy treści literatury przedmiotu oraz analizy prawnonormatywnej obowiązujących aktów prawa dotyczących kształcenia na odległość. W pierwszej części ukazana jest szkoła jako instytucja inkluzji normatywnej w perspektywie historycznej oraz współczesnej. W drugiej naświetlono obszary wykluczenia w kontekście wprowadzanych zmian związanych z pandemią.

\section{Introduction}

School, in both the colloquial and scientific senses, is perceived as an educational, socializing, and didactic-oriented institution, while its protective and guardianship function is talked and written about less often. Nevertheless, experience shows that for many children school is a place that meets their basic needs to a higher degree than their parents do, or at least it effectively compensates for the inadequate care and protection that they suffer from in many Polish families. In the time of crisis caused by the COVID-19 pandemic, the protective and guardianship functions of schools have also escaped the attention of policymakers and the educational community, leaving thousands of "invisible students" on their own in the world of distance learning.

Our purpose is to outline the problem of remote education during the pandemic in light of the issue of children's rights and child advocacy. We believe that the situation in schools during this period opens up new dimensions of school exclusion. 
The study was based on a perusal of the literature on the subject and a legal and normative scrutiny of the binding legal acts on distance education. The article may inspire the educators, teachers, and school principles to think about the options for securing the guardianship and care functions of schools and educational facilities during the pandemic.

\section{School as an Institution of Normative Inclusion}

The history of education and upbringing, which has been progressing since the idea of the right to education first appeared, is the history of the circulation of concepts, models, and principles of educational policy. In many of these theories, the child was not at the center of care and education: the child was "an object of character-molding" and indoctrination-a tool in the hands of the educational and religious policy of nations. They often experienced violence, abuse, and methods that were inconsistent with the contemporary understanding of the "best interests" of the child (see Magier 2013; Kusztal 2018; Arczewska 2017; Turczyk, Kusztal 2019). However, this does not change the fact that it was school that contributed to the emancipation of the child and the perception of childhood as a significant phase of human development.

The view of school as an institution that liberates children and crystalizes their individual identity has existed since the end of the $17^{\text {th }}$ century, when, as Philippe Ariès claims, the child was separated from the rest of the family and from the community, and went off to school (Ariès 1995: 8-9). Ariès, in his Centuries of Childhood [original title: L'enfant et la vie familiale sous l'ancien régime] stresses that "school ... removed the child from adult society" (1995: 413), thereby constituting the first link in the process of recognizing children as a social group. As a consequence of the introduction of compulsory education and the development of educational institutions in most European countries in the $19^{\text {th }}$ century, there was a gradual change in the position of the child in the family and society, which in turn improved the protection of their subjectivity, including their legal status.

The establishment of educational statism was not grounded in the noble ideas of protecting the rights and subjectivity of the child, but mainly in religious and civilizational settings, deeply rooted in the concepts of a conflict-solving, paternalistic, administrative, redistributive, and educating state (Bała 2009: 38), which is fundamentally contrary to the contemporary notions of freedom and emancipation. However, the analysis of the history of education as a right of every human being shows that the popularization of education played emancipatory and protective roles. Thus, school as an institution became the first universal tool for the protection of children's rights. 
From the historical perspective, it can be said that the normalization of the right to education — the first version of it — did not take place until 1923, when the International Save the Children Union adopted the first version of the Declaration of the Rights of the Child, the so-called Geneva Declaration (Mausersberg 1990: 190). Within the scope of this article, there is no room to discuss the legal particularities of this law or its adoption by the international community, but it is undoubtedly the first normative legislation in the history of children's rights for the universal education of children: the first milestone in creating a legal protection of childhood and, as part of it, children's education. The idea of a child's right to education in its final form was enshrined in the provisions of Arts. 28 and 29 of the Convention on the Rights of the Child, which was adopted by the United Nations General Assembly on November 20, 1989.

The provisions of the current educational law in Poland clearly indicate three basic functions that the school performs (Act of December 14, 2016). Its statutory task is to conduct didactic, educational, and protective activities. Also, the core curriculum for general education for all types of schools and institutions specifies these three functions (Regulation of the Minister of National Education of February 14, 2017), and the educational role of the school as a place of social prevention and of children's comprehensive development are the major slogans of educational reforms (cf. Dudzikowa 2004; Michalski 2016). For over twenty years, one of the cardinal principles behind the philosophy of introducing systematic changes into the educational system has been to provide equal educational opportunities for children and adolescents (Serafin 2018: 1122). The path to this equalization of education, according to the successive reforms, was to lead to the diagnosed psychophysical needs of the student by providing adequate help to children at school and adjusting the didactic and educational process. Specific measures for providing and organizing psychological and pedagogical assistance in schools—as well as the tasks of psychological and pedagogical counseling centers, detailed rules of their operation, and conditions of the education, upbringing, and care of disabled children and adolescents, as well as those socially maladjusted and at risk of social maladjustment-are specified in the ordinances of the Minister Education and determined by the specific tasks of school authorities, school principals, and teachers in the field of equalizing educational opportunities for students.

What is the reality in Polish schools? We are asking this question at a time when school teaching has been temporarily changed: schools have switched to distance learning due to the COVID-19 pandemic. 


\section{The Normative Aspect of a Child's Right to Education During a Pandemic: Areas of Exclusion}

Distance learning, which was introduced in Poland during the pandemic by the Regulation of the Minister of National Education of March 20, 2020 on Special Solutions in the Period of Temporary Limitation of the Functioning of Educational System Facilities in Connection with the Prevention, Counteraction, and Combating of COVID-19, was to secure the constitutional right of every child to education based on the principle of equal educational opportunities while educational institutions were closed because of the epidemic. Therefore, this regulation should identify adequate tools and strategies to support the educational, character-building, and preventative role of school in times of crisis.

It is probably too early for any definitive assessment, ${ }^{1}$ and that is not the purpose of this analysis. We are only expressing our concern about the situation we are experiencing, and as educators and researchers of education we are suggesting the need for research and intervention in a time of crisis, but also for solutions reaching far into the future (Jaskulska, Turczyk 2020).

Overnight, as a result of the spread of the COVID-19 virus, students, teachers, and parents became active participants in the process of re-building the school institution from the ground up. In addition, the integration of information and communication technologies into school education suddenly became the shared responsibility of thousands of teachers, students, and their families. This is a completely normal and necessary occurrence, since Polish schools have so far insufficiently used new technologies in teaching. Distance learning is a wonderful alternative to traditional classroom education. The problem is, however, that the Polish school was not and is still not prepared for such a leap in information technology, both financially and in its educational and preventative work. As a consequence, this has caused serious limitations in access to education for many Polish students.

The Regulation of the Ministry of National Education did not propose a coherent concept of measures to weather the crisis (Regulation of March 20, 2020). The focus was only on the didactic mission of schools, while completely overlooking their educational and protective role. The task of the school during the pandemic was reduced to sending teaching materials through various channels and checking the students' level of knowledge acquisition. As for the choice of these channels, the legislature gave the directors of educational institutions full freedom and, simultaneously, responsibility. The regulation and the justification for it only focus on ensuring the continuity

1 We finished writing this article in mid-May 2020, just two months after the announcement in Poland of the changes in the school structures and routines during the COVID-19 pandemic. 
of transferring knowledge to students and of monitoring their progress. No other educational goals were set, as if the Ministry forgot how important, especially in such an emotionally difficult time for students, the protective care and the guardianship of schools is.

A limitation of the educational and care role of school, which was also noticed previously by people who care about education and described as a major problem ailing the Polish school system (see Jaskulska 2015; Nawrocki 2016; Żytko 2020), was highlighted during the crisis. The implementation of the core curriculum and the need to assess students and conduct exams seem to fully exhaust the meaning assigned to "school" during the pandemic.

There are numerous examples of grassroots initiatives, such as online educators' offices, support groups for students and parents, teacher self-help groups on social networks, and free tutoring conducted by students and scouts. ${ }^{2}$ These initiatives originated from people's real needs that can traced back to didactic or technical issues, finding solutions in spontaneously created social networks. The teachers, who see their work as a mission of nurture and care, try to put "a human face" on distance learning by making sure to build and maintain a relationship of trust with students and motivating them to get involved.

However, this is not a standard that all public schools can afford, and it is certainly not an approach promoted by the minister's guidelines. Consequently, distance learning exacerbates social inequalities, not only due to the lack of access to computer hardware, software, the Internet, and good housing conditions-which many Polish families struggle with-but also because of insufficient IT infrastructure in schools themselves or insufficient preparation of the teachers in this area. The biggest problem, if we look at the school from the point of view of its educational and protective function (which is what we are suggesting), is that for many boys and girls of all ages, physical school was a safe haven with a hot meal and caring, attentive adults—or at least a place free of violence, which some of them experience in their homes. For children from orphanages, schoolchildren with special educational needs, children from special-purpose schools and educational centers, emergency care shelters, or correctional facilities, school is not only the textbooks, grades, and tests. It is much more than that. It is an opportunity to learn how to live, to find respite from the difficulties of everyday life, to be given the attention and support of adults, and to experience educational success—-sometimes the only success they experience in life (Poleszak, Pyżalski 2020).

\footnotetext{
2 For example, EduAkcja (https://www.facebook.com/programeduakcja) or free study assistance provided by students (https://www.facebook.com/kolonaukowerazem).
} 
While it's difficult for us to find and name an impromptu solution to the hardware and technical problems - the need to stay at home simply condemns us to these imperfect forms of e-learning - we recommend that the Minister of Education should organize a network of pedagogical and psychological support (even by phone) with real concern for these students, for those families who truly need it now. We also imagine how the situation would change if, instead of receiving more and more unrealistic guidelines, the teachers were encouraged to support their students emotionally, even at the cost of not covering the entire syllabus, and if, instead of being burdened with more and more didactic tasks, the children who used to get subsidized meals received a wholesome meal which they could count on at school. If, by virtue of a regulation, at least additional homeroom hours were introduced in every Polish school, and if the range of materials for distance learning included proposals for prevention programs in the area of children's and adolescents' mental health, psychological and pedagogical counseling centers would transfer the support for students, parents, and teachers to remote interventions. ${ }^{3}$ It also seems necessary to reflect on the situation of children at risk of becoming maladjusted, or children from culturally and economically neglected backgrounds, where remote learning has not been delivered so far, not for technological reasons, but because of the parents' mentality and lack of parental capacity. First of all, however, the help, support, and care which — like teaching —is a statutory and moral duty of Polish schools, is not being provided. In the normative framework of thinking about school during the epidemic, these children are unlawfully excluded from the educational system. In a realistic perspective on the condition of Polish education, it would be reasonable to ask about the enrollment rate, which is a measure of the universality of education, and an accurate diagnosis of the scale of children dropping out of the system. This would help us determine the real numbers and percentages of children who have not been able to cope with the challenges of distance learning and have been excluded from exercising their right to education. This is their fundamental right, guaranteed and protected by law, which is "the absolute minimum" in the EU (van Dijk, Hoof 1990: 468).

3 From May 6, 2020 pursuant to the Regulation of the Minister of National Education of April 29, 2020 amending the Regulation on the Temporary Limitation of the Functioning of Education Facilities in Connection with Preventing, Counteracting, and Combating COVID-19 (Journal of Laws 2020, item 780) and the Regulation of the Minister of National Education of April 29, 2020 amending the Regulation on Special Solutions in the Period of Temporary Limitation of the Functioning of Education Facilities in Connection with the Prevention, Counteraction, and Combating of COVID-19 (Journal of Laws 2020, item 781), the physical work of psychological clinics was restored. On the other hand, the legislature allowed the clinics to carry out interventions which do not require appointments in person and can be accomplished with remote methods and techniques. As a consequence, in fact, the children have not returned to the appointments and classes in most clinics nationwide and the panels have not been convening. Parents applying for psychologists' certificates receive replies that the panel may meet in September at the earliest, which makes it impossible to obtain a ruling before the start of the new school year. 
Who will stand up for equal educational opportunities for these children? Who is guarding their rights today?

Another "invisible" group is the children of doctors, nurses, paramedics, trade workers, and social services and logistics workers, i.e., whose parents who must leave their homes and fight the epidemic on the front lines. In their homes, often alonebecause the legislature assumes that a surge in independence occurs at age 8 - children who are supposed to be learning remotely are scared and their basic need for safety is not being met. There is no special didactic, protective, or psychological support for them, as the Ministry has not organized the "necessary care" in schools and kindergartens, while the whole society absolutely needs their parents now. Only an ordinance from the Ministry of National Education (Regulation of April 29, 2020) introduced the possibility of organizing child care in nurseries and kindergartens for the youngest children starting May 6. However, is excludes children over the age of 7 years from the right to such support and this "necessary care" is not addressed to the whole of society.

One solution to this predicament could be to stop awarding grades and change exam schedules, while recommending that teachers' and students' energy and the potential of new technologies be used to create support networks. This does not mean giving up teaching, but shifting the emphasis. Without safeguarding the educational and protective functions of school, even the most skillfully executed remote teaching will not achieve the goals intended for the educational system.

In our opinion, the solutions proposed by the Minister also escalate the tensions between teachers and parents. The latter blame the principals and the teachers for the educational difficulties that their families are now encountering, while forgetting that schools were not prepared for distance learning. Teachers also do not have the proper conditions to lead such lessons. They are forced to work in a significantly different way than in regular classes with teenagers and children, and the outcomes of their new instructional practices are criticized even though they have good intentions. Not everyone is prepared for the realities of e-learning and-just like parents - they are grappling with many challenges, such as technological barriers and arranging an appropriate space in their homes. Through all of this, they are experiencing a didactic and methodological solitude. From day to day, they are forced to act under time pressures and - almost always - to produce and use their own materials. Distance learning pathways and the use of new technologies in teaching have only recently become an element of university education preparing students for the teaching profession. Therefore, many teachers wrestle with limitations in their own skills, material and didactic restrictions, and the expectations of principals and parents who are concerned about the educational future of their children. The minister has not provided for any special methodological or psychological support for them. 
We can say that teachers abruptly got stuck in a situation "in which they must recognize the new reality and learn to participate in the changes taking place, the quality of which will largely depend on both their duration and continuity and on the possibility of changing oneself" (Staszewicz 2009: 58), while their anxiety stems from the awareness of being alone. The need to adjust to the new reality of the pandemic, both personally and professionally, and to learn to embrace the changes taking place often exceeds the possibilities and competences of teachers. ${ }^{4}$

The propaganda of educational success and national unity in face of the pandemic creates the illusion that if something is not working, then individuals - the teachers-are to blame, or the insufficient number of computers in homes, but not the government's solutions. However, the regulations are of enormous importance in times of crisis, and the substantive foundations of the solutions adopted in them decide whether one of the fundamental principles of law-equality in access to educationis ensured. As a result of factual (pandemic) and legal circumstances (the legislative reaction of educational authorities), the right of children to education is currently being violated. The identification and diagnosis of this new "educational barrier" (Kozak 2013) $)^{5}$ absent from the literature so far, should be essential in influencing the participation of society in education and for taking corrective and preventative actions. The verification and implementation of educational standards is an integral component of the right to education (Jasudowicz 2005: 384). Today, securing this right is a challenge for researchers of the educational reality and for public authorities.

A school is a group of people who are interlinked in a network of relationships. A school is much more than the transmission, absorption, and testing of knowledge. We do not find this truth in the minister's distance learning guidelines. Concentrating both the normative and the instrumental efforts only on school's didactic function and disregarding its guardianship and protective role towards students during a pandemic leads to violations of the children's right to education. The lack of concern for the protection of children's rights additionally magnifies the inequalities that already existed before March 2020 and weakens the assessment of "remote schooling," which has been reduced to an extremely narrow definition of "education." Moreover, the victims of the situation and of the new directives may be not only the children, but the teachers as well, since the gap between them and their more digitally skilled students is increasing. Let us remember that the teachers did not receive adequate technical and

\footnotetext{
4 Various centers are conducting research on this topic, for example, https://centrumcyfrowe.pl/edukacjazdalna; Jaskulska, Jankowiak 2020.

5 The term educational barrier "defines the consequences of an unfavorable situation, event or problem, resulting from, for example, the circumstances in which the student found himself/herself, the didactic and educational situation, and the educational policies which limit the child's right or completely prevent them from participating in educational processes" (Kozak 2013: 138).
} 
methodological support in conducting distance learning classes. Thus, good online teaching practices have been the result of the efforts of individual schools, principals, and teachers - not the solutions of the school system (and sometimes despite them). These events and their long-term consequences require further research.

\section{Bibliography}

Act of December 14, 2016 - Education law, Journal of Laws 2020, item 374. (2016).

Arczewska M. (2017). Dobro dziecka jako przedmiot troski spotecznej [The welfare of the child as an object of social concern], Krakow: Nomos.

Ariès P. (1995). Historia dziecinstwa [History of childhood], Gdansk: MARABUT.

Bała P. (2009). Konstytucyjne prawo do nauki a polski system oświaty [The constitutional right to education and the Polish educational system], Warsaw: Von Borowiecky.

Centrum Cyfrowe. (2020). Edukacja zdalna w czasie pandemii [Remote education during a pandemic]. https://centrumcyfrowe.pl/edukacja-zdalna (accessed: 15.05.2020).

Convention on the Rights of the Child of November 20, 1989, Journal of Laws no. 120, item 526. (1989).

Dudzikowa M. (2004). Mit o szkole jako miejscu wszechstronnego rozwoju ucznia: eseje etnopedagogiczne [The myth of the school as a place of a student's comprehensive development: Ethnopedagogical essays], Krakow: Impuls.

Jaskulska S. (2015). Ocenianie zachowania uczniów na stopień. Szkolna obsesja porządku $w$ świetle matematycznej teorii chaosu [Assessing student behavior with grades: School obsession with order in light of the mathematical theory of chaos], "Fundamentals of Education,” vol. 8, pp. 187-197. DOI: 10.16926/pe.2015.08.14.

Jaskulska S., Jankowiak B. (2020). Distance learning in a pandemic [Unpublished manuscript].

Jaskulska S., Turczyk M. (2020). Potrzebne jest wsparcie [Support is needed]. https:// ja-nauczyciel.pl/news/prof-uam-dr-hab-sylvania-jaskulska-pnecne-jest-wsparcie/ (accessed: 15.05.2020).

Jasudowicz T. (2005). Prawo do nauki [The right to education], [in:] B. Gronowska (ed.), Prawa i ich ochrona: podręcznik dla studentów prawa $i$ administracji [Rights and their protection: a textbook for students of law and administration], Toruń: Dom Organizatora.

Kozak M. (2013). Prawo dziecka do edukacji. Zatożenia pedagogiczno-prawne i bariery realizacyjne [The child's right to education: Pedagogical and legal principles and barriers to implementation], Warsaw: RPD Publishing House.

Kusztal J. (2018). Dobro dziecka $w$ resocjalizacji. Aspekty pedagogiczne i prawne [The welfare of the child in rehabilitation: Pedagogical and legal aspects], Krakow: Jagiellonian University Press.

Kusztal J., Turczyk M. (2019). Dzieciństwo, dziecko i jego dobro w perspektywie Korczakowskiej [Childhood, the child, and child welfare according to Korczakowska], "Problemy Wczesnej Edukacji," 3(46), pp. 7-15. DOI: 10.26881/pwe.2019.46.01. 
Magier P. (2013). O pedagogicznym rozumieniu dobra dziecka [On the pedagogical understanding of child welfare], [in:] A. Daszykowska, A. Łuczyński (eds.), Dziecko $w$ przestrzeni życia spotecznego [The child in the space of social life], Stalowa Wola: Catholic University of Lublin.

Mauersberg S. (ed.). (1990). Dzieje szkolnictwa i pedagogiki specjalnej [The history of education and special education], Warsaw: PWN.

Michalski Ł. (2016). Pole minowe. O grach polityki z edukacja [Minefield: On politicians' games with education], [in:] M. Dudzikowa, S. Jaskulska (eds.), Twierdza. Szkota $w$ metaforze militarnej. Co $w$ zamian? [Fortress - School in a military metaphor: What in exchange?], Warsaw: Wolters Kluwer, pp. 246-264.

Nawrocki R. (2016). Edukacja jako pole gry [Education as a playing field], [in:] M. Dudzikowa, S. Jaskulska (eds.), Twierdza. Szkota $w$ metaforze militarnej. Co $w$ zamian? [Fortress - School in a military metaphor: What in exchange?], Warsaw: Wolters Kluwer, pp. 137-151.

Poleszak W., Pyżalski J. (2020), Psychologiczna sytuacja dzieci i mtodzieży $w$ dobie epidemii [The psychological situation of children and adolescents during an epidemic], [in:] J. Pyżalski (ed.), Edukacja w czasach pandemii wirusa COVID-19. Z dystansem o tym, co robimy obecnie jako nauczyciele [Education during the COVID-19 pandemic: Not entirely serious about what we are doing today as teachers], Warsaw: EduAkcja.

Regulation of the Minister of National Education of February 14, 2017, on the Core Curriculum of Preschool Education and the Core Curriculum of General Education for Primary School, including Students with Moderate or Severe Intellectual Disability, General Education for First-degree Vocational School, General Education for Special Job-training School, and General Education for Post-secondary School, Journal of Laws, item 356. (2017).

Regulation of the Minister of National Education of March 20, 2020 on Special Solutions in the Period of Temporary Limitation of the Functioning of Education System Facilities in Connection with the Prevention, Counteraction, and Combating of COVID-19, Journal of Laws 2020, item 493. (2020).

Regulation of the Minister of National Education of April 29, 2020 amending the Regulation on Special Solutions for the Period of Temporary Limitation of the Functioning of Education System Facilities in Connection with the Prevention, Counteraction, and Combating of COVID-19, Journal of Laws 2020, item 781. (2020).

Regulation of the Minister of National Education of April 29, 2020 amending the Regulation on the Temporary Limitation of the Functioning of Education System Facilities in Relation to the Prevention, Counteraction, and Combating of COVID-19, Journal of Laws 2020, item 780. (2020).

Serafin T. (2018). Potrzeby edukacyjne uczniów i wychowanków [Educational needs of students and pupils], [in:] K. Gawroński, S.M. Kwiatkowski (eds.), Meritum Prawo Oświatowe, Warsaw: Wolters Kluwer.

Staszewska M. (2009). Nauczyciel cybergeneracji [The cybergeneration teacher], "Education and Dialogue," no. 03/2009. 
van Dijk P., Hoof G. (1990). Theory and practice of the European Convention of Human Rights, Boston: Kluwer Law and Taxation.

Żytko M. (2020). Edukacja w ramionach standaryzacji-czy autonomia jest jeszcze możliwa? [Education in the grip of standardization: Is autonomy still possible?], "Czas Kultury," no. 1, pp. 29-38.

\section{ADDRESS FOR CORRESPONDENCE}

Małgorzata Turczyk

Jagiellonian University

e-mail:m.turczyk@uj.edu.pl

Sylwia Jaskulska

Adam Mickiewicz University in Poznań

e-mail: sylwia.jaskulska@gmail.com 